\author{
K. Rokosz ${ }^{1}$, T. Hryniewicz ${ }^{1}$, K. Pietrzak ${ }^{1}$, P. Sadlak ${ }^{1}$, J. Valíček $^{2}$ \\ ${ }^{1}$ Koszalin University of Technology, Faculty of Mechanical Engineering, Department of En- \\ gineering and Informatics Systems, Division of Bioengineering and Surface Electrochemistry, \\ Racławicka 15-17, 75-620 Koszalin, Poland \\ ${ }^{2}$ Institute of Physics, Faculty of Mining and Geology, V̌̌B-Technical University of Ostrava, \\ 17. listopadu 15, 70833 Ostrava, Czech Republic \\ rokosz@tu.koszalin.plT
}

\title{
FABRICATION AND CHARACTERISATION OF POROUS, CALCIUM ENRICHED COATINGS ON TITANIUM AFTER PLASMA ELECTROLYTIC OXIDATION UNDER DC REGIME
}

\begin{abstract}
The purpose of this work is to produce and characterize (chemical composition and roughness parameters) porous coatings enriched in calcium and phosphorus on the titanium (CP Titanium Grade 2) by plasma electrolytic oxidation. As an electrolyte, a mixture of phosphoric acid $\mathrm{H}_{3} \mathrm{PO}_{4}$ and calcium nitrate $\mathrm{Ca}\left(\mathrm{NO}_{3}\right)_{2} \cdot 4 \mathrm{H}_{2} \mathrm{O}$ was used. Based on obtained EDS and roughness results of PEO coatings, the effect of PEO voltages on the chemical composition and surface roughness of porous coatings was determined. With voltage increasing from $450 \mathrm{~V}$ to 650 $\mathrm{V}$, the calcium in PEO coatings obtained in freshly prepared electrolyte was also found to increase. In addition, the $\mathrm{Ca} / \mathrm{P}$ ratio increased linearly with voltage increasing according to the formula $\mathrm{Ca} / \mathrm{P}=0.035 \cdot \mathrm{U}+0.176$ (by $\mathrm{wt} \%$ ) and $\mathrm{Ca} / \mathrm{P}=0.03 \cdot \mathrm{U}+0.13$ (by at $\%$ ). It was also noticed that the surface roughness increases with the voltage increasing, what is related to the change in coating porosity, i.e. the higher is the surface roughness, the bigger are pores sizes obtained.
\end{abstract}

Keywords: Plasma Electrolytic Oxidation PEO, Micro Arc Oxidation MAO, SEM, titanium, porous coatings, concentrated phosphoric acid $\mathrm{H}_{3} \mathrm{PO}_{4}$, calcium nitrate $\mathrm{Ca}\left(\mathrm{NO}_{3}\right)_{2} \cdot 4 \mathrm{H}_{2} \mathrm{O}$

\section{INTRODUCTION}

Titanium is used in many different ways all over the world, mostly for aerospace parts in jet engines and aircraft, but recently it has been used widely in the prosthetic industry and the artificial heart. It is used both in bioengineering, because of its biological compatibility, and for the catalysts construction. It should be also noted that titanium, despite of its higher prices than stainless steels, in many cases cannot be replaced by cheaper materials due to its mechanical and corrosive properties as well as very good biocompatibility. Fabrication of a suitable metal-based material for use in construction of implants or endoprosthesis is a huge challenge for engineer, who expected to obtain the material with appropriate strength, weight, and Young's modulus, which may have similar chemical composition and mechanical properties as a bone tissue. In addition, it should be resistant to corrosion in the environment of the liv- 
ing organism. It has to be also pointed that the surfaces which may be used as biomaterials should be treated additionally by several methods to improve their osseointegration. To prepare the nano-layers with expected chemical composition and mechanical properties, the electropolishing (EP) [1], magnetoelectropolishing (MEP) [2], and high-current density electropolishing (HDEP) [3] processes are employed, while for obtaining the micro scale layers, the Plasma Electrolytic Oxidation (PEO), known also as Micro Arc Oxidation (MAO) [4-6], should be used. That method may be used to oxidize inter alia the titanium [7-10], its alloys (Ti6Al4V [11-12], Ti6Al7Nb [13], NiTi [14], TiNbZr [15], TiNbZrSn [16]) as well as niobium [18] and tantalum [19]. In addition, it has to be pointed that PEO coatings may be enriched also in other elements, i.e. antibacterial copper [20] or zinc [21].

In the present paper, the Authors describe the porous surfaces obtained on titanium after PEO treatment under DC regime of voltage in the electrolyte containing concentrated $(85 \%)$ phosphoric acid $\mathrm{H}_{3} \mathrm{PO}_{4}$ and zinc nitrate $\mathrm{Ca}\left(\mathrm{NO}_{3}\right)_{2} \cdot 4 \mathrm{H}_{2} \mathrm{O}$. A focus was directed on the calciumto-phosphorus $(\mathrm{Ca} / \mathrm{P})$ ratio in the porous coatings obtained.

\section{METHOD AND EXPERIMENTAL SET UP}

Plasma Electrolytic Oxidation/Micro Arc Oxidation process was used for treating the samples of CP Titanium Grade 2 with dimensions $10 \mathrm{~mm} \times 10 \mathrm{~mm} \times 2 \mathrm{~mm}$. The plasma electrolytic oxidation (PEO) was performed at the voltages of $450 \mathrm{~V}_{\mathrm{DC}}, 550 \mathrm{~V}_{\mathrm{DC}}$ and $650 \mathrm{~V}_{\mathrm{DC}}$. The electrolyte consisted of a concentrated $85 \%$ analytically pure $\mathrm{H}_{3} \mathrm{PO}_{4}(98 \mathrm{~g} / \mathrm{mole})$ acid, one liter, with $500 \mathrm{~g}$ of zinc nitrate $\mathrm{Ca}\left(\mathrm{NO}_{3}\right)_{2} \cdot 4 \mathrm{H}_{2} \mathrm{O}$ dissolved in it.

Scanning Electron Microscope (SEM) FEI Quanta 650 FEG equipped with EnergyDispersive X-ray Spectroscopy (EDS) for surface analysis was employed. The microscope operated under the following conditions: voltage $15 \mathrm{kV}$, current 8-10 nA, beam diameter $6 \mu \mathrm{m}$, decreased vacuum in the chamber with the pressure of $50 \mathrm{~Pa}$. The identification of spectral lines was performed by means of spectral decomposition using the holographic peak deconvolution function. For graphical presentation of obtained data, the box-and-whisker plots with minimum, maximum, lower and upper quartiles and median, were used.

A computerized HOMMEL TESTER T800 system of Hommelwerke GmbH to study of surface roughness measurement was used. It was equipped with sliding measuring head Waveline 60 Basic/51808 and the sensor TKL100/17 MO435005. Measuring needle beam was equal to $3.5 \mu \mathrm{m}$ with its angle of $87^{\circ}$. The tracing, evaluation and single measuring lengths, equal to $4.8,4.0$ and $0.8 \mathrm{~mm}$, respectively, were used. Due to the porous surface, the non-contact methods for surface roughness [22] were not possible to be used, inter alia because of the uncertainties in measurement results [23]. According to the EN ISO 4287:1999 (Geometrical product specifications (GPS) - surface texture: profile method-terms, definitions and surface texture parameters) and DIN 4768 (Determination of values of surface roughness parameters Ra, Rz, Rmax using electrical contact (stylus) instruments; concepts and measuring conditions) standards, the following roughness parameters have been measured: arithmetic mean of the sum of roughness profile values $(\mathrm{Ra})$, mean peak-to-valley height $\left(\mathrm{Rz}^{\mathrm{DIN}}\right)$, ten-point height $\left(\mathrm{Rz}^{\mathrm{ISO}}\right)$, total height of the roughness profile $(\mathrm{Rt})$. 


\section{RESULTS}

In Figure 1, the SEM images with different zoom lens $(500 \times, 1000 \times, 5000 \times)$ and EDS spectrum of porous surface obtained on titanium after the PEO treatment at $450 \mathrm{~V}_{\mathrm{DC}}$ for 3 minutes, in the electrolyte consisting of $500 \mathrm{~g} \mathrm{Ca}\left(\mathrm{NO}_{3}\right)_{2} \cdot 4 \mathrm{H}_{2} \mathrm{O}$ in $1000 \mathrm{~mL}$ concentrated $\mathrm{H}_{3} \mathrm{PO}_{4}$, are presented. In Figure 2, the basic statistics of obtained EDS data, are shown. The average calcium content of the porous coating obtained on titanium in a new and fresh electrolyte after PEO treatment at $450 \mathrm{~V}_{\mathrm{DC}}$ is equals to $9.4 \pm 1.2 \mathrm{wt} \%(8.8 \pm 1.1 \%$ at $\%)$, while phosphorus and titanium are $45.4 \pm 0.5 \mathrm{wt} \%(55.4 \pm 0.4 \mathrm{at} \%)$ and $45.3 \pm 1.6 \mathrm{wt} \%(35.8 \pm 1.4$ at $\%$ ), respectively. The coating also obtained at $450 \mathrm{~V}_{\mathrm{DC}}$ in 3 minutes in the same electrolyte, which was already once used, contains the following amounts of calcium $8.8 \pm 0.5 \mathrm{wt} \%(8.5 \pm$ 0.4 at $\%)$, phosphorus $51.1 \pm 0.6 \mathrm{wt} \%(41.4 \pm 0.6$ at $\%)$ and titanium $50.2 \pm 1.0 \mathrm{wt} \%(40.4 \pm$ $0.9 \mathrm{at} \%)$. The third PEO processing in the same electrolyte contains the following amounts of elements: calcium $9.8 \pm 0.7 \mathrm{wt} \%(9.3 \pm 0.6$ at $\%)$, phosphorus $44.3 \pm 0.5 \mathrm{wt} \%(54.4 \pm 0, \%)$ and titanium $45.9 \pm 0.8 \mathrm{wt} \%(36.4 \pm 0.7 \mathrm{at} \%)$.

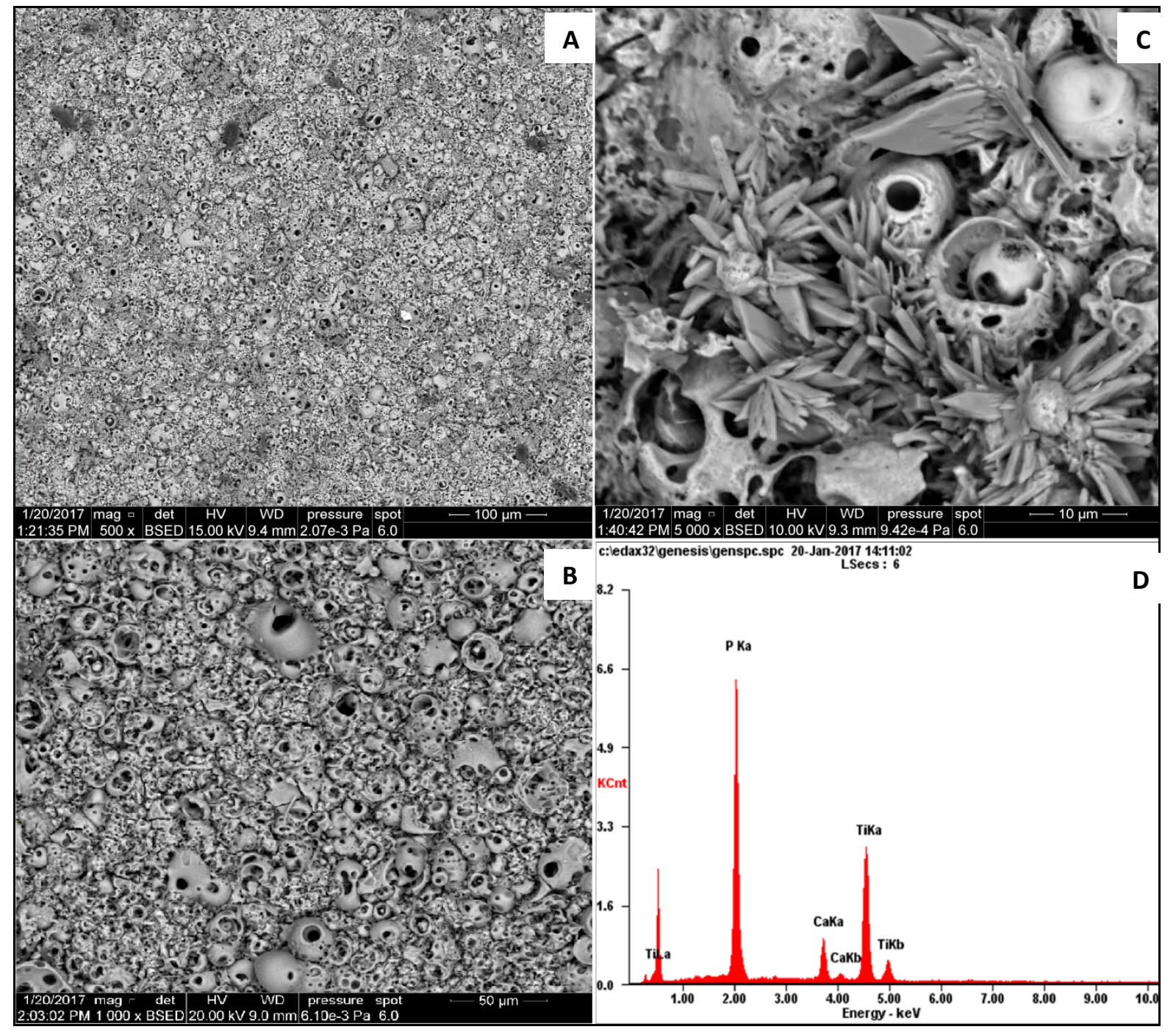

Fig. 1. SEM images $(A-C)$ and EDS spectrum of coating obtained on Titanium after PEO treatment at $450 V_{D C}$ for 3 minutes in the electrolyte consisting of $500 \mathrm{~g} \mathrm{Ca}\left(\mathrm{NO}_{3}\right)_{2} \cdot 4 \mathrm{H}_{2} \mathrm{O}$ in $1000 \mathrm{~mL} \mathrm{H}_{3} \mathrm{PO}_{4}$; SEM magnifications: $500 \times(\mathrm{A})$, $1000 \times(B), 5000 \times(C)$; magnification for EDS analysis: 500× 


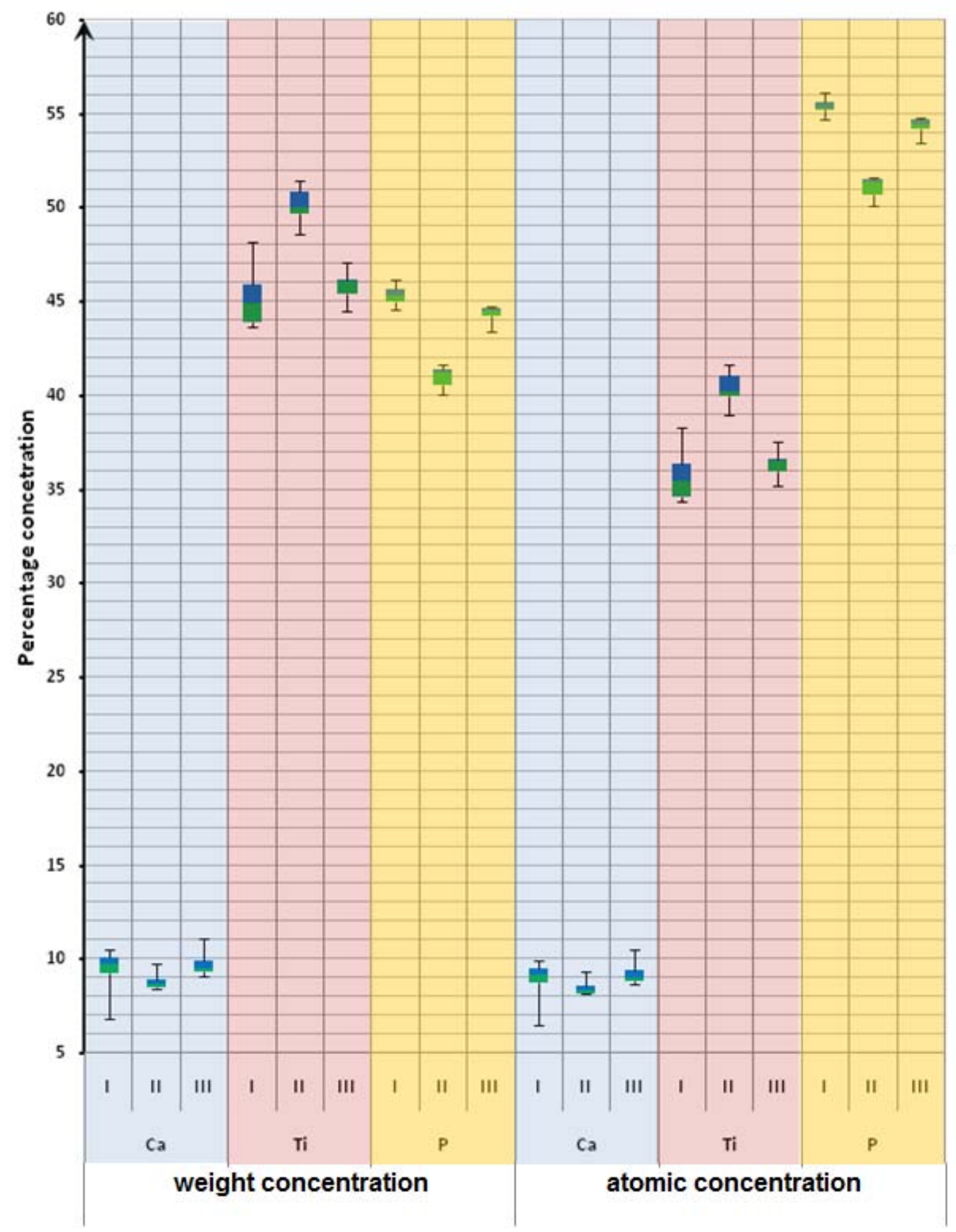

Fig. 2. Basic statistics of EDS results of coating obtained on Titanium after PEO treatment at $450 \mathrm{~V}_{\mathrm{DC}}$ for 3 minutes in the electrolyte consisting of $500 \mathrm{~g} \mathrm{Ca}\left(\mathrm{NO}_{3}\right)_{2} \cdot 4 \mathrm{H}_{2} \mathrm{O}$ in $1000 \mathrm{~mL} \mathrm{H}_{3} \mathrm{PO}_{4}$

In Figure 3, the SEM images with different zoom lens $(500 \times, 1000 \times, 5000 \times)$ and EDS spectrum of porous surface obtained on titanium after the PEO treatment at $550 \mathrm{~V}_{\mathrm{DC}}$ in 3 minutes, in the electrolyte consisting of $500 \mathrm{~g} \mathrm{Ca}\left(\mathrm{NO}_{3}\right)_{2} \cdot 4 \mathrm{H}_{2} \mathrm{O}$ in $1000 \mathrm{~mL}$ concentrated $\mathrm{H}_{3} \mathrm{PO}_{4}$, are presented. In Figure 4, the basic statistics of obtained EDS data, are shown. The 
average content of calcium in the coating obtained on titanium in a new electrolyte after PEO treatment at $550 \mathrm{~V}_{\mathrm{DC}}$ is equals to $10.1 \pm 0.2 \mathrm{wt} \%(9.7 \pm 0.2 \%)$, while the contents of phosphorus and titanium are $40.6 \pm 0.3 \mathrm{wt} \%(50.6 \pm 0.3 \mathrm{at} \%)$ and $49.3 \pm 0.2 \mathrm{wt} \%(39.7 \pm 0.2 \mathrm{at} \%)$, respectively. The coating also obtained at $550 \mathrm{~V}_{\mathrm{DC}}$ in 3 minutes in the electrolyte only once used contains the following amounts of calcium $9.9 \pm 0.5 \mathrm{wt} \%(9.5 \pm 0.4 \mathrm{at} \%)$, phosphorus $42.7 \pm 0.3 \mathrm{wt} \%(52.7 \pm 0.3$ at $\%)$ and titanium $47.3 \pm 0.5 \%(37.8 \pm 0.5 \mathrm{at} \%)$. The third PEO processing in the same electrolyte contains the following amounts of calcium $8.9 \pm 0.1 \mathrm{wt} \%$ $(8.6 \pm 0.1 \mathrm{at} \%)$, phosphorus $39.7 \pm 0.5 \mathrm{wt} \%(49.8 \pm 0,5 \%)$ and titanium $51.3 \pm 0.6 \mathrm{wt} \%$ $(41.6 \pm 0.5 \mathrm{at} \%)$.

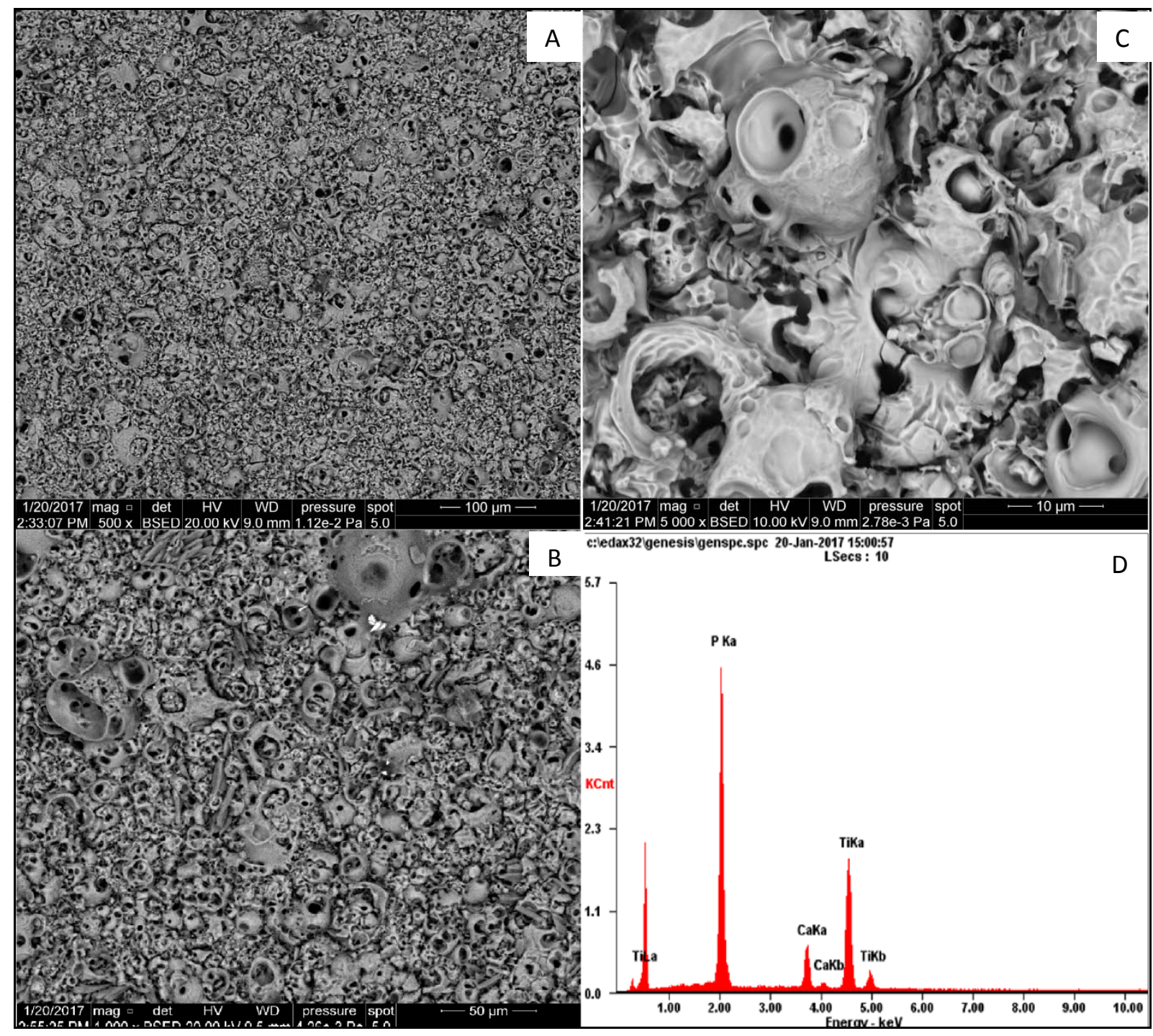

Fig. 3. SEM images $(A-C)$ and EDS spectrum of coating obtained on Titanium after $P E O$ treatment at $550 V_{D C}$ for 3 minutes in the electrolyte consisting of $500 \mathrm{~g} \mathrm{Ca}\left(\mathrm{NO}_{3}\right)_{2} \cdot 4 \mathrm{H}_{2} \mathrm{O}$ in $1000 \mathrm{~mL} \mathrm{H}_{3} \mathrm{PO}_{4}$; SEM magnifications: $500 \times(\mathrm{A})$, $1000 \times(B), 5000 \times(C)$; magnification for EDS analysis: 500× 


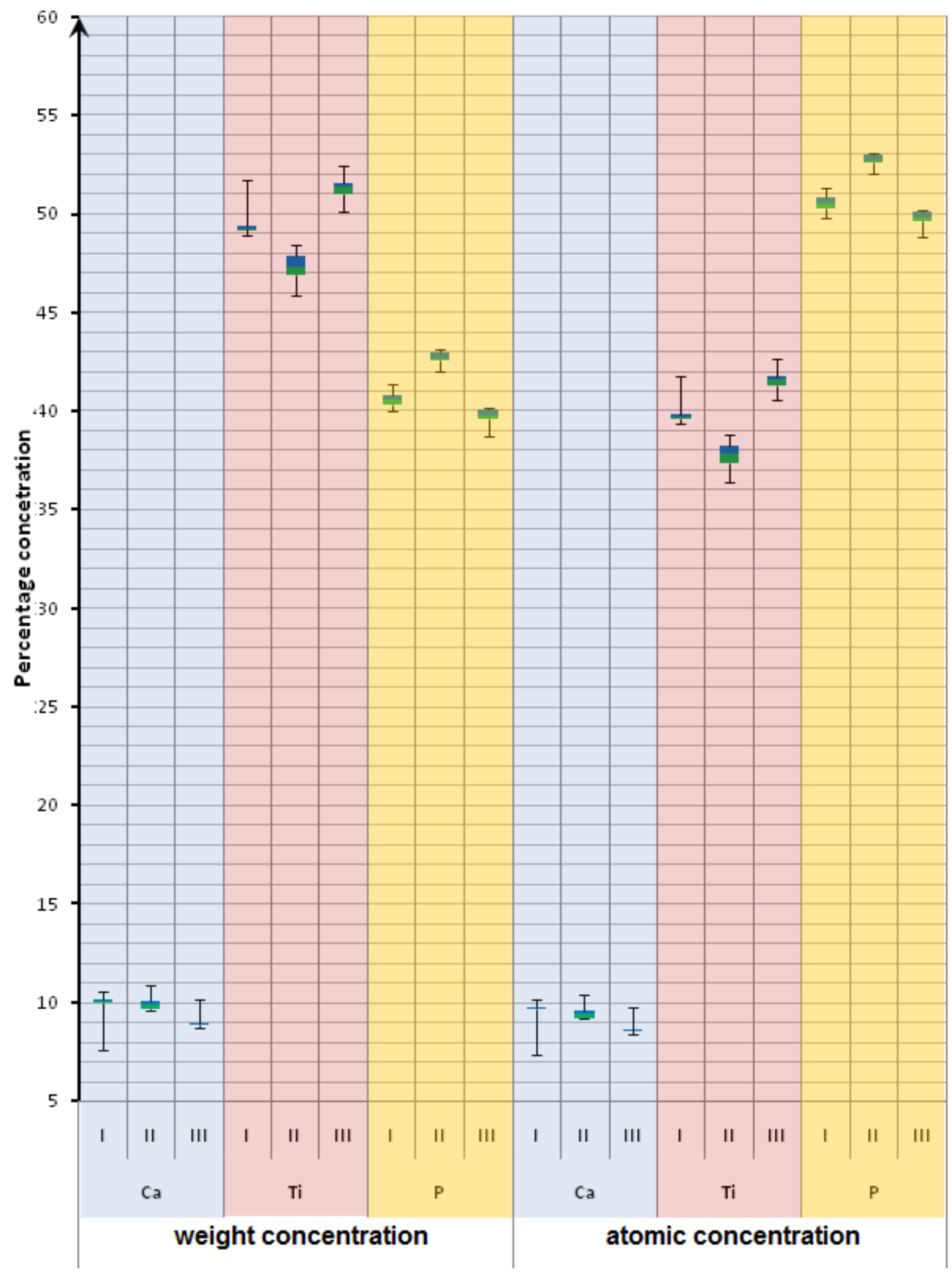

Fig. 4. Basic statistic of EDS results of coating obtained on Titanium after PEO treatment at $550 \mathrm{~V}_{\mathrm{DC}}$ for 3 minutes in the electrolyte consisting of $500 \mathrm{~g} \mathrm{Ca}\left(\mathrm{NO}_{3}\right)_{2} \cdot 4 \mathrm{H}_{2} \mathrm{O}$ in $1000 \mathrm{~mL} \mathrm{H}_{3} \mathrm{PO}_{4}$

In Figure 5, the SEM images with different zoom lens $(500 \times, 1000 \times, 5000 \times)$ and EDS spectrum of porous surface obtained on titanium after the PEO treatment at $650 \mathrm{~V}_{\mathrm{DC}}$ in 3 minutes, in the electrolyte consisting of $500 \mathrm{~g} \mathrm{Ca}\left(\mathrm{NO}_{3}\right)_{2} \cdot 4 \mathrm{H}_{2} \mathrm{O}$ in $1000 \mathrm{~mL}$ concentrated 
$\mathrm{H}_{3} \mathrm{PO}_{4}$, are presented. In Figure 6, the basic statistics of obtained EDS data, are shown. The average content of calcium in the coating obtained on titanium in a new electrolyte after PEO treatment at $650 \mathrm{~V}_{\mathrm{DC}}$ is $10.7 \pm 0.1 \mathrm{wt} \%(10.4 \pm 0.1 \mathrm{at} \%)$, while the contents of phosphorus and titanium are $37.6 \pm 0.4 \mathrm{wt} \%(47.5 \pm 0.5$ at $\%)$ and $51.7 \pm 0.4 \mathrm{wt} \%(42.1 \pm 0.4 \mathrm{at} \%)$, respectively. The coating obtained at $650 \mathrm{~V}_{\mathrm{DC}}$ in the electrolyte only once used contains calcium $10.1 \pm 0.2 \mathrm{wt} \%(9.8 \pm 0.2$ at $\%)$, phosphorus $38.8 \pm 0.4 \mathrm{wt} \%(48.7 \pm 0.5$ at $\%)$ and titanium $51.1 \pm 0.3 \%(41.5 \pm 0.3 \mathrm{at} \%)$. The third sample processed in the same electrolyte contains calcium $10.2 \pm 0.6 \mathrm{wt} \%(9.9 \pm 0.6$ at $\%)$, phosphorus $39.8 \pm 1.0 \mathrm{wt} \%(49.8 \pm 1 \mathrm{at} \%)$ and titanium $49.9 \pm 1.4 \mathrm{wt} \%(40.3 \pm 1.4 \mathrm{at} \%)$.

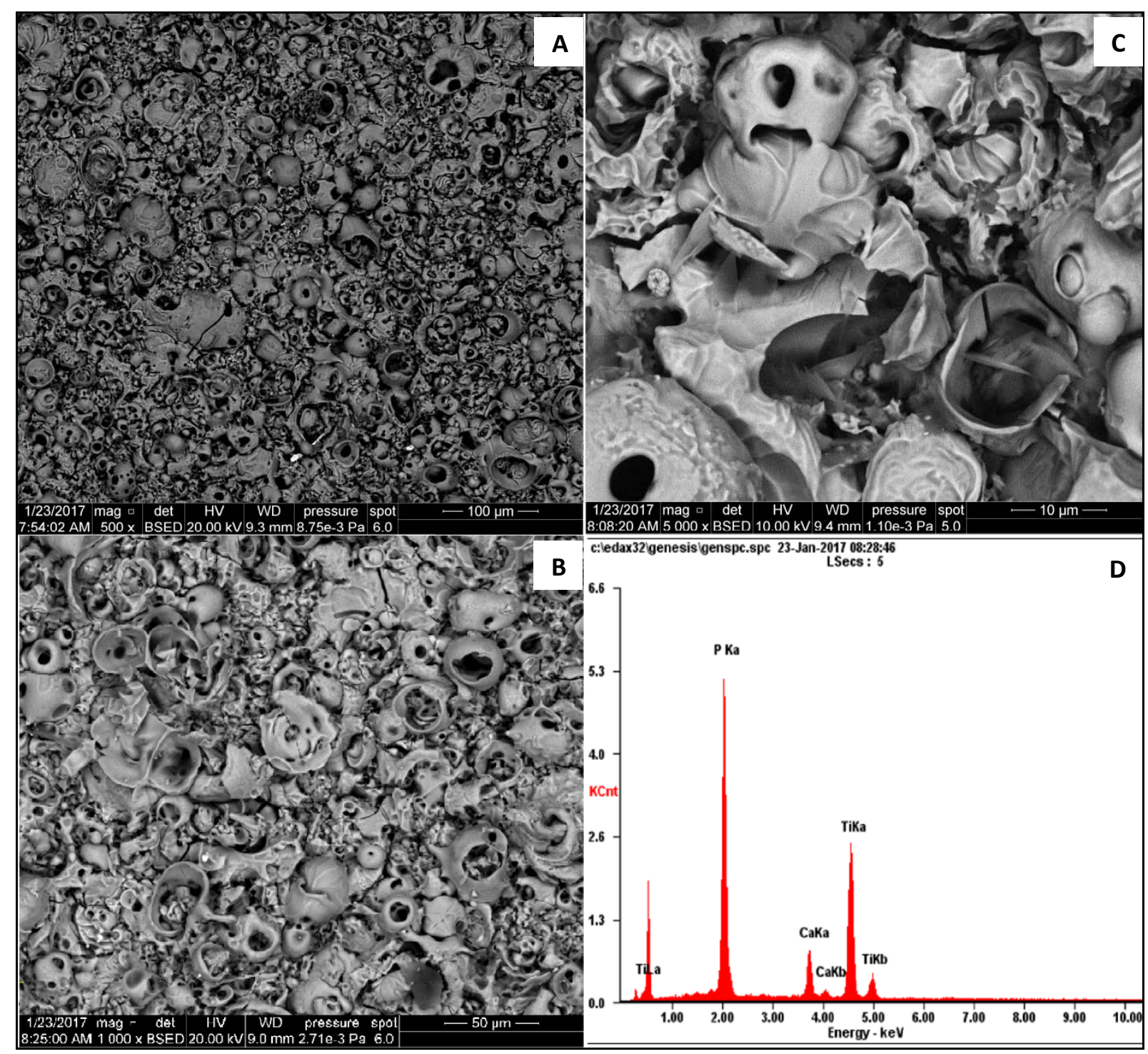

Fig. 5. SEM images (A-C) and EDS spectrum of coating obtained on Titanium after PEO treatment at $650 \mathrm{~V}_{D C}$ for 3 minutes in the electrolyte consisting of $500 \mathrm{~g} \mathrm{Ca}\left(\mathrm{NO}_{3}\right)_{2} \cdot 4 \mathrm{H}_{2} \mathrm{O}$ in $1000 \mathrm{~mL} \mathrm{H}_{3} \mathrm{PO}_{4}$; SEM magnifications: $500 \times(\mathrm{A})$, $1000 \times(B), 5000 \times(C)$; magnification for EDS analysis: $500 \times$ 


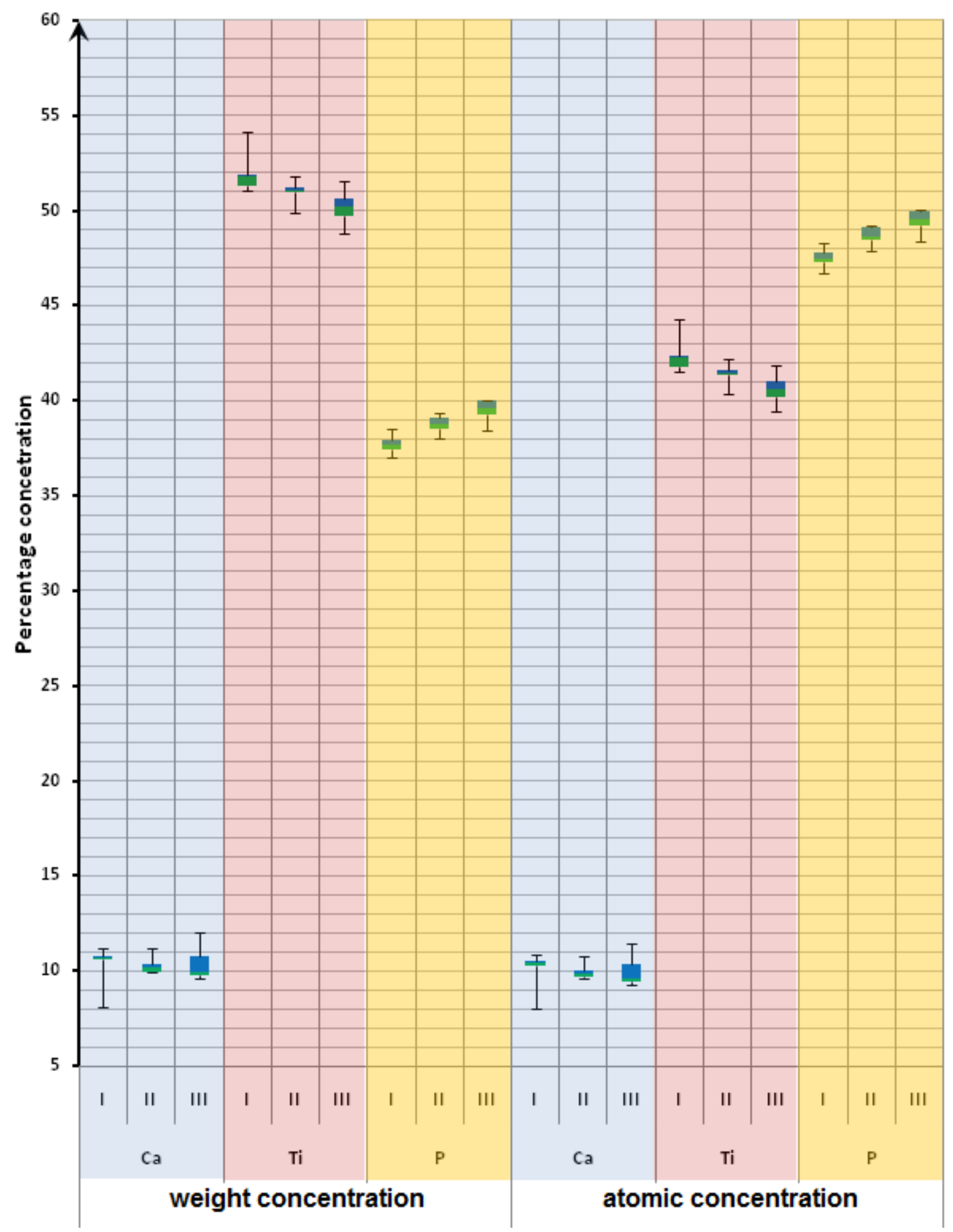

Fig. 6. Basic statistic of EDS results of coating obtained on Titanium after PEO treatment at $650 V_{D C}$ for 3 minutes in the electrolyte consisting of $500 \mathrm{~g} \mathrm{Ca}\left(\mathrm{NO}_{3}\right)_{2} \cdot 4 \mathrm{H}_{2} \mathrm{O}$ in $1000 \mathrm{~mL} \mathrm{H}_{3} \mathrm{PO}_{4}$

In Figure 7, the $\mathrm{Ca} / \mathrm{P}$ ratios of coatings obtained on Titanium after $\mathrm{PEO}$ treatment at $650 \mathrm{~V}_{\mathrm{DC}}$ in 3 minutes in the electrolyte consisting of $500 \mathrm{~g} \mathrm{Ca}\left(\mathrm{NO}_{3}\right)_{2} \cdot 4 \mathrm{H}_{2} \mathrm{O}$ in $1000 \mathrm{~mL}$ 
$\mathrm{H}_{3} \mathrm{PO}_{4}$, are presented. Based on these results, it should be stated that both the chemical composition and the porosity of these coatings depend both on the PEO voltage and on the "electrolyte aging". In order to enable any comparison of the obtained PEO coatings, it was decided to calculate the $\mathrm{Ca} / \mathrm{P}$ ratios (Figure 7), which clearly indicates the differences between the obtained coatings. The results show that the increasing of PEO voltage causes a linear increasing of the calcium-to-phosphorus ratio, what may be mathematically described by the following equations: $\mathrm{Ca} / \mathrm{P}=0.035 \cdot \mathrm{U}+0.176$ (based on $\mathrm{wt} \%$ ) and $\mathrm{Ca} / \mathrm{P}=0.03 \cdot \mathrm{U}+0.13$ (based on at $\%$ ).

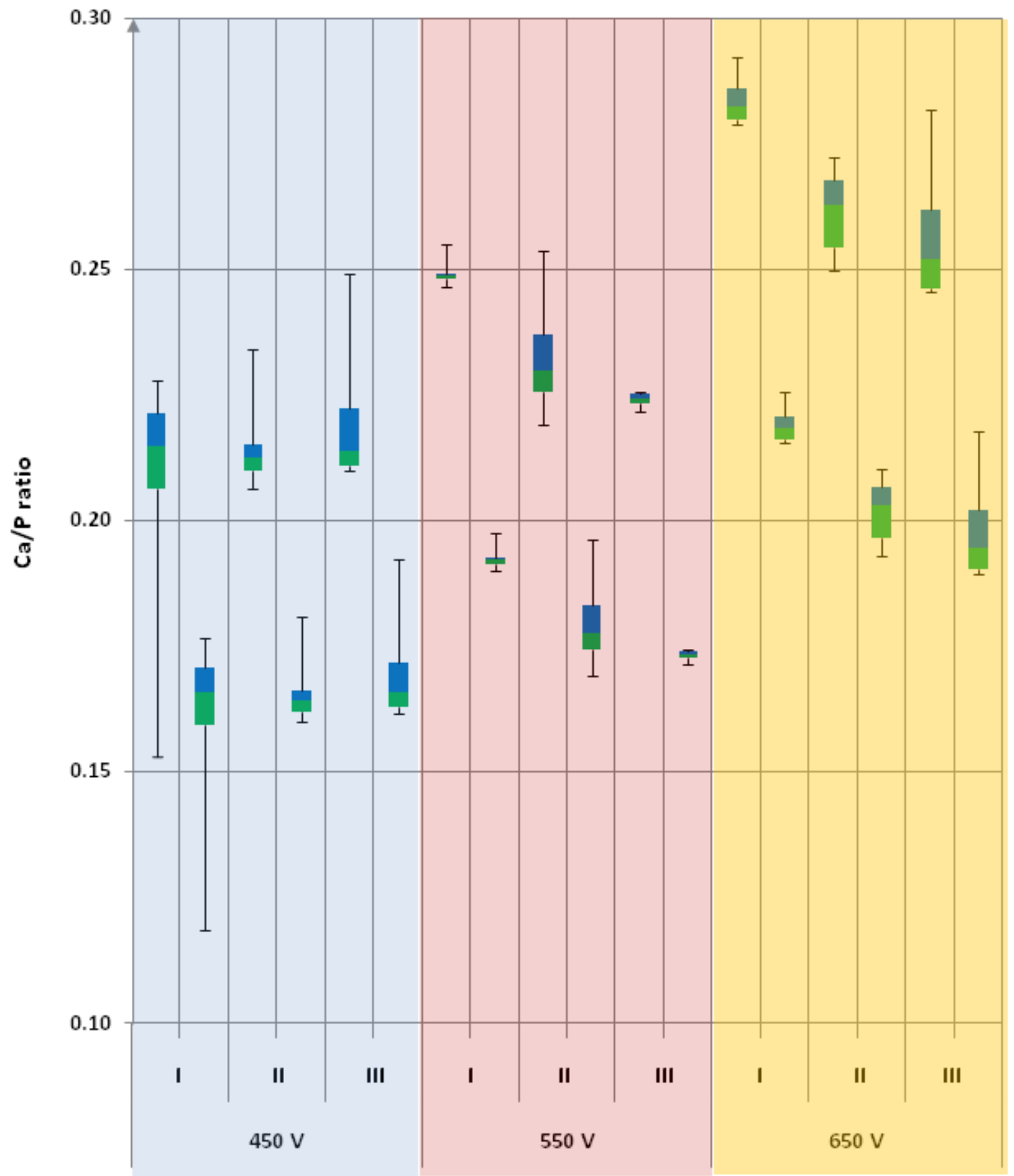

Fig. 7. Ca/P ratios of coating obtained on Titanium after $\mathrm{PEO}$ treatment at $650 \mathrm{~V}_{\mathrm{DC}}$ for 3 minutes in the electrolyte consisting of $500 \mathrm{~g} \mathrm{Ca}\left(\mathrm{NO}_{3}\right)_{2} \cdot 4 \mathrm{H}_{2} \mathrm{O}$ in $1000 \mathrm{~mL} \mathrm{H}_{3} \mathrm{PO}_{4}$ 
In Figure 8, 2D roughness parameters ( $\left.\mathrm{Ra}, \mathrm{Rz}, \mathrm{Rz}^{\mathrm{ISO}}, \mathrm{Rt}\right)$ for PEO surfaces, are presented. It is visible that with PEO voltage increasing, the increasing of roughness parameters values is observed. In case of the first samples treated at $450 \mathrm{~V}_{\mathrm{DC}}$ in a fresh electrolyte, the following $\mathrm{Ra}(1.86 \pm 0.46 \mu \mathrm{m}), \mathrm{Rz}(11.01 \pm 2.13 \mu \mathrm{m}), \mathrm{Rz}^{\mathrm{ISO}}(12.82 \pm 4.02 \mu \mathrm{m})$ and $\operatorname{Rt}(16.78 \pm 4.71 \mu \mathrm{m})$ were found. The roughness parameters for the second samples in the same electrolyte after PEO treatment also at $450 \mathrm{~V}$ were equal: $\mathrm{Ra}(1.88 \pm 0.08 \mu \mathrm{m}), \mathrm{Rz}(12.11 \pm 1.24 \mu \mathrm{m}), \mathrm{Rz}^{\mathrm{ISO}}$ $(12.78 \pm 0.90 \mu \mathrm{m})$, Rt $(17.45 \pm 2.81 \mu \mathrm{m})$; and for the third one, the Ra $(1.45 \pm 0.14 \mu \mathrm{m}), \mathrm{Rz}$ $(10.50 \pm 1.91 \mu \mathrm{m}), \mathrm{Rz}^{\mathrm{ISO}}(11.31 \pm 1.80 \mu \mathrm{m})$ and $\mathrm{Rt}(16.46 \pm 2.76 \mu \mathrm{m})$ were found. The PEO coating, which was obtained at $550 \mathrm{~V}_{\mathrm{DC}}$ as the first sample in new electrolyte, may be characterized by $\mathrm{Ra}(2.17 \pm 0.17 \mu \mathrm{m}), \mathrm{Rz}(13.83 \pm 1.74 \mu \mathrm{m}), \mathrm{Rz}^{\text {ISO }}(14.48 \pm 0.90 \mu \mathrm{m})$ and $\mathrm{Rt}$ $(20.11 \pm 3.51 \mu \mathrm{m})$. The roughness parameters of second one in the solution only once used at $450 \mathrm{~V}$ is higher, i.e. $\mathrm{Ra}(2.43 \pm 0.15 \mu \mathrm{m}), \mathrm{Rz}(15.42 \pm 2.49 \mu \mathrm{m}), \mathrm{Rz}^{\mathrm{ISO}}(15.69 \pm 1.92 \mu \mathrm{m})$ and Rt $(19.17 \pm 3.41 \mu \mathrm{m})$. In case of the third one, processed in the same electrolyte, the roughness parameters were as follows: $\operatorname{Ra}(2.04 \pm 0.18 \mu \mathrm{m}), \mathrm{Rz}(13.28 \pm 0.92 \mu \mathrm{m}), \mathrm{Rz}^{\mathrm{ISO}}(14.77 \pm 0.82 \mu \mathrm{m})$ and Rt $(19.07 \pm 2.13 \mu \mathrm{m})$. After the PEO treatment at $650 \mathrm{~V}_{\mathrm{DC}}$ of titanium sample in a new electrolyte its surface has the following roughness parameters: $\mathrm{Ra}(4.86 \pm 0.52 \mu \mathrm{m}), \mathrm{Rz}$ $(27.88 \pm 3.08 \mu \mathrm{m}), \mathrm{Rz}^{\mathrm{ISO}}(30.17 \pm 3.10 \mu \mathrm{m}), \mathrm{Rq}(6.27 \pm 0.72 \mu \mathrm{m})$ and $\mathrm{Rt}(37.08 \pm 3.74 \mu \mathrm{m})$. Next sample in the same electrolyte has a higher roughness, characterized by the following parameters: $\operatorname{Ra}(3.53 \pm 0.29 \mu \mathrm{m}), \operatorname{Rz}(20.56 \pm 2.27 \mu \mathrm{m}), \mathrm{Rz}^{\mathrm{ISO}}(21.54 \pm 2.29 \mu \mathrm{m})$ and $\operatorname{Rt}(27.28 \pm 5.09$ $\mu \mathrm{m})$. In case of the third one, the obtained results were as follows: $\mathrm{Ra}(4.33 \pm 0.46 \mu \mathrm{m}), \mathrm{Rz}$ $(25.76 \pm 2.10 \mu \mathrm{m}), \mathrm{Rz}^{\mathrm{ISO}}(26.94 \pm 2.61 \mu \mathrm{m}), \operatorname{Rq}(5.59 \pm 0.64 \mu \mathrm{m})$ and $\operatorname{Rt}(33.85 \pm 5.88 \mu \mathrm{m})$.

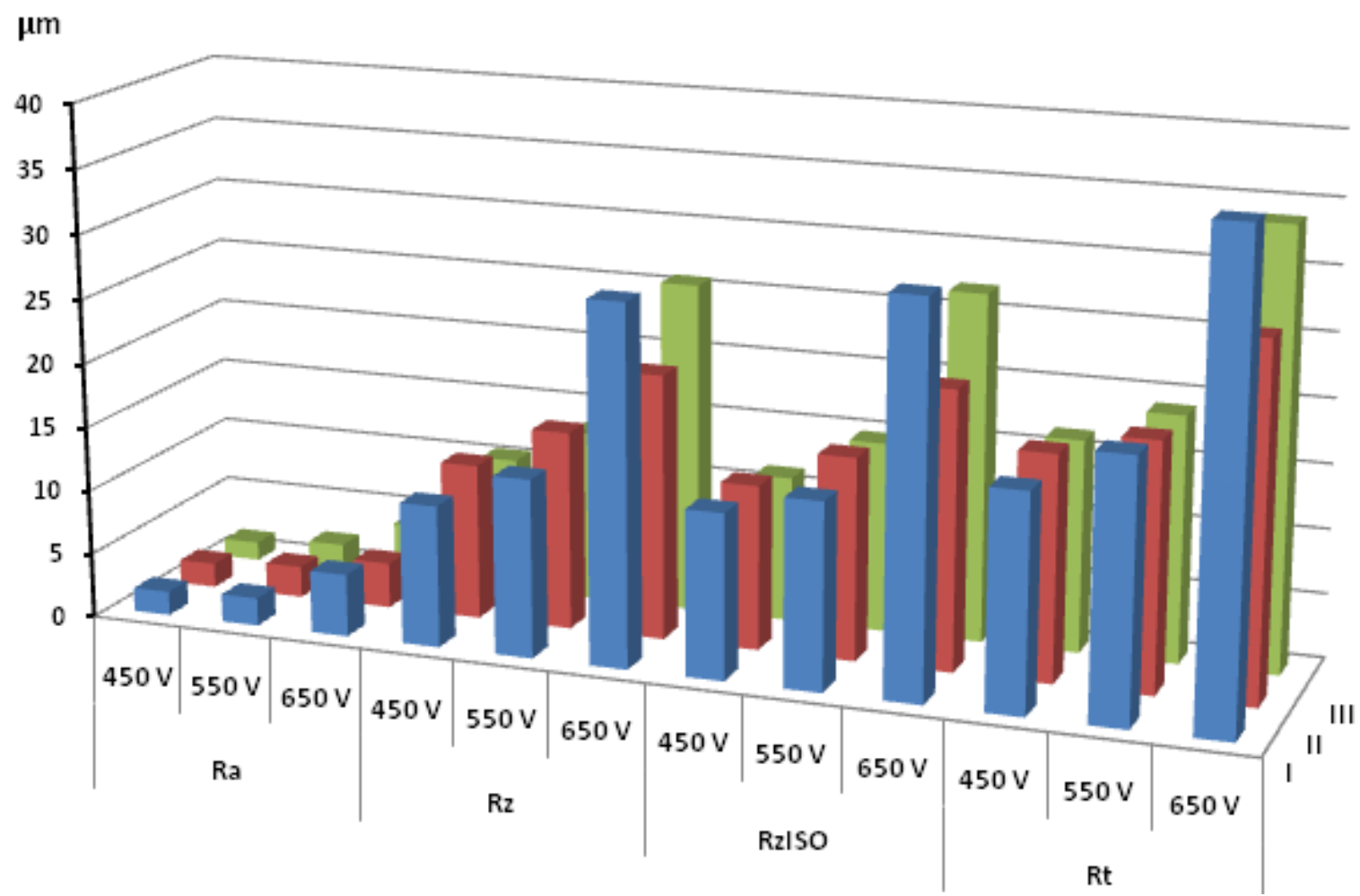

Fig. 8. Roughness parameters of porous coating obtained on Titanium after PEO treatment at $650 \mathrm{~V}_{\mathrm{DC}}$ for 3 minutes in the electrolyte consisting of $500 \mathrm{~g} \mathrm{Ca}\left(\mathrm{NO}_{3}\right)_{2} \cdot 4 \mathrm{H}_{2} \mathrm{O}$ in $1000 \mathrm{~mL} \mathrm{H}_{3} \mathrm{PO}_{4}$ 


\section{CONCLUSIONS}

In this paper, the results of the porous coatings obtained by $\mathrm{PEO}$ treatment on titanium, with using of electrolytes containing of $500 \mathrm{~g} \mathrm{Ca}\left(\mathrm{NO}_{3}\right)_{2} \cdot 4 \mathrm{H}_{2} \mathrm{O}$ in $1 \mathrm{~L} \mathrm{H}_{3} \mathrm{PO}_{4}$, are described. Based on the results obtained, one may conclude that:

- it is possible to obtain porous coatings containing calcium and phosphorus on titanium substrate by plasma electrolytic oxidation at voltages of $450 \mathrm{~V}$ to $650 \mathrm{~V}$ in an electrolyte based on concentrated phosphoric acid $\mathrm{H}_{3} \mathrm{PO}_{4}$ and calcium nitrate $\mathrm{Ca}\left(\mathrm{NO}_{3}\right)_{2} \cdot 4 \mathrm{H}_{2} \mathrm{O}$

- the chemical composition of the PEO porous coatings depends on the PEO voltage; the higher voltage, the more calcium in the PEO coating is obtained

- $\mathrm{Ca} / \mathrm{P}$ ratio increases linearly with increasing voltage from $450 \mathrm{~V}$ to $650 \mathrm{~V}$

- the surface roughness of the porous coatings depends on the PEO voltage; with PEO voltage increasing, the surface roughness increases, too

- PEO treatment with potential of $650 \mathrm{~V}$ results in obtaining the surface roughness which is approximately twice as high in comparison with that one recorded for the coating obtained at $450 \mathrm{~V}$.

\section{ACKNOWLEDGMENTS}

This work was supported by subsidizing by Grant OPUS 11 of National Science Centre, Poland, with registration number 2016/21/B/ST8/01952, titled "Development of models of new porous coatings obtained on titanium by Plasma Electrolytic Oxidation in electrolytes containing phosphoric acid with addition of calcium, magnesium, copper and zinc nitrates".

Special acknowledgments are directed to Professor Czesław Łukianowicz, DSc PhD, head of Metrology and Quality Division, former Dean at the Faculty of Mechanical Engineering of KUT, for making available a computerized HOMMELTESTER T800 system of Hommelwerke GmbH.

\section{REFERENCES}

1. Jacquet F.J., Le polissage electrolytique, Dunod, Paris, 1968.

2. Rokosz K., Hryniewicz T., Raaen S., Cr/Fe ratio by XPS spectra of magnetoelectropolished AISI 316L SS fitted by Gaussian-Lorentzian shape lines, TehnickiVjesnik-Technical Gazette, 21(3) (2014), 533-538.

3. Rokosz K., Lahtinen J., Hryniewicz T., Rzadkiewicz S., XPS depth profiling analysis of passive surface layers formed on austenitic AISI 304L and AISI 316L SS after high-current-density electropolishing, Surface and Coatings Technology, 276 (2015), 516-520.

4. Aliasghari S., Plasma Electrolytic Oxidation of Titanium, PhD Thesis of Faculty of Engineering and Physical Sciences, The University of Manchester School of Materials, (2014), 223 pages.

5. Teh T.H., Berkani A., Mato S., Skeldon P., Thompson G.E., Habazaki H., Shimizu K., Initial stages of plasma electrolytic oxidation of titanium, Corrosion Science, 45 (2003), 2757-2768.

6. Wang Y., Jiang B., Lei T., Guo L., Dependence of growth features of microarc oxidation coatings of titanium alloy on control modes of alternate pulse, Materials Letters, 58 (2004), 1907-1911. 
7. Gnedenkov S.V., Sharkeev Y.P., Sinebryukhov S.L., Khrisanfova O.A., Legostaeva E.V., Zavidnaya A.G., Puz' A.V., Khlusov I.A., Opra D.P., Functional coatings formed on the titanium and magnesium alloys as implant materials by plasma electrolytic oxidation technology: fundamental principles and synthesis conditions, Corrosion Review, 34(1-2) (2016), 65-83.

8. Simka W., Sadowski A., Warczak M., Iwaniak A., Dercz G., Michalska J., Maciej A., Modification of titanium oxide layer by calcium and phosphorus, Electrochimica Acta, 56(24) (2011), 8962-8968.

9. Han Y., Hong S.H., Xu K.W., Structure and in vitro bioactivity of titania-based films by microarc oxidation, Surface and Coatings Technology, 168 (2003), 249-258.

10. Fei C., Hai Z., Chen C., Yangjian X., Study on the tribological performance of ceramic coatings on titanium alloy surfaces obtained through microarc oxidation, Progress in Organic Coatings, 64 (2009), 264-267.

11. Krzakala A., Mlynski J., Dercz G., Michalska J., Maciej A., Nieuzyla L., Simka W, Modification of Ti-6Al-4V alloy surface by EPD-PEO process in $\mathrm{ZrSiO} 4$ suspension, Archives of Metallurgy and Materials, 59(1) (2014), 199-204.

12. Rokosz K., Hryniewicz T., Raaen S., Development of Plasma Electrolytic Oxidation for improved Ti6Al4V biomaterial surface properties, The International Journal of Advanced Manufacturing Technology, 85 (2016), 2425-2437.

13. Simka W., Nawrat G., Chlode J., Maciej A., Winiarski A., Szade J., Radwanski K., Gazdowicz J., Electropolishing and anodic passivation of Ti6A17Nb alloy, Przemysł Chemiczny, 90(1) (2011), 84-90.

14. Rokosz K., Hryniewicz T., Raaen S., SEM, EDS and XPS analysis of nanostructured coating obtained on NiTi biomaterial alloy by Plasma Electrolytic Oxidation (PEO), Tehnički vjesnikTechnical Gazette, 24(1) (2017), 193-198.

15. Rokosz K., Hryniewicz T., Raaen S., Chapon P., Development of copper-enriched porous coatings on ternary $\mathrm{Ti}-\mathrm{Nb}-\mathrm{Zr}$ alloy by Plasma Electrolytic Oxidation, The International Journal of Advanced Manufacturing Technology, 89(9) (2017), 2953-2965.

16. Rokosz K., Hryniewicz T., Raaen S., Chapon P., Investigation of porous coatings obtained on Ti$\mathrm{Nb}-\mathrm{Zr}-\mathrm{Sn}$ alloy biomaterial by Plasma Electrolytic Oxidation: Characterisation and Modelling, The International Journal of Advanced Manufacturing Technology, 87(9) (2016), 3497-3512.

17. Rokosz K, Hryniewicz T, Dalibor M, Raaen S,, Valiček J,, Dudek Ł,, Harničarova M., SEM, EDS and XPS Analysis of the Coatings Obtained on Titanium after Plasma Electrolytic Oxidation in Electrolytes Containing Copper Nitrate, Materials, 9(5) (2016), 1-12.

18. Rokosz K., Hryniewicz T., Comparative SEM and EDX analysis of surface coatings created on niobium and titanium alloys after Plasma Electrolytic Oxidation (PEO). Tehnički vjesnikTechnical Gazette, 24(2) (2017), 465-472.

19. Rokosz K., Hryniewicz T., Chapon P., Raaen S., ZschommlerSandim H.R., XPS and GDOES characterisation of porous coating enriched with copper and calcium obtained on Tantalum via Plasma Electrolytic Oxidation, Journal of Spectroscopy, Article ID 7093071 (2016) (7 pages); http://dx.doi.org/10.1155/2016/7093071

20. Rokosz K., Hryniewicz T., Raaen S., Malorny W., Fabrication and characterisation of porous coatings obtained by plasma electrolytic oxidation, Journal of Mechanical and Energy Engineering, 1(1|41) (2017), 23-30.

21. Rokosz K., Hryniewicz T., Pietrzak K., Malorny W., SEM and EDS characterization of porous coatings obtained on titaniumby plasma electrolytic oxidation in electrolyte containing concentrated phosphoric acid with zinc nitrate, Advances in Materials Science, 17(2|52) (2017), 41-54. 
22. Kusnerova M., Rokosz K., Kusnerova M., Barcova K., Brazina D., Noncontact method for surface roughness measurement after machining, Measurement Science Review, 12(5) (2012), 184 88; DOI:10.2478/v10048-012-0028-3

23. Kusnerova M, Valiček J., Harničarova M., Hryniewicz T., Rokosz K., Palkova Z., Vaclavik V., Repka M., Bendova M., A proposal for simplifying the method of evaluation of uncertainties in measurement results, Measurement Science Review, 13(1) (2013), 1-6; DOI:10.2478/msr-20130007 